\title{
Dynamics and mass balance of four large East Antarctic outlet glaciers
}

\author{
Leigh A. STEARNS \\ Department of Geology and Center for Remote Sensing of Ice Sheets, University of Kansas, Lawrence, KS 66045, USA \\ E-mail: stearns@ku.edu
}

\begin{abstract}
The East Antarctic ice sheet (EAIS) is Earth's largest reservoir of fresh water and has the potential to raise sea level by $\sim 50 \mathrm{~m}$. A significant amount of the ice sheet's mass is discharged by outlet glaciers draining through the Transantarctic Mountains, the balance characteristics of which are largely unknown. Here the mass balance is estimated for four glaciers draining ice from the EAIS through the Transantarctic Mountains into the Ross Sea embayment: David, Mulock, Byrd and Nimrod glaciers. Remote-sensing observations are used to map changes in ice flow and surface elevation, and ultimately to compute the mass balance of each glacier using the input-output method and three separate estimates for accumulation rate. Results computed using this method indicate small positive balances for David $\left(2.41 \pm 1.31 \mathrm{Gt} \mathrm{a}^{-1}\right)$, Mulock $\left(1.91 \pm 0.84 \mathrm{Gt} \mathrm{a}^{-1}\right)$ and Nimrod $\left(0.88 \pm 0.39 \mathrm{Gt} \mathrm{a}^{-1}\right)$ glaciers, and a large positive imbalance for Byrd Glacier $\left(21.67 \pm 4.04 \mathrm{Gta}^{-1}\right)$. This large imbalance for Byrd Glacier is inconsistent with other observations, and is likely due to an overestimation of accumulation rates across large regions of the interior catchment.
\end{abstract}

\section{INTRODUCTION}

Large outlet glaciers and ice streams are the primary means by which ice is transported from the interior of Antarctica to the ocean (e.g. Rignot and Thomas, 2002). These glaciers are known to change speed on a range of timescales, ranging from days (Bindschadler and others, 2003) to decades (Joughin and others, 2003; Stearns and others, 2005) to centuries (Retzlaff and others, 1993; Hulbe and Fahnestock, 2007). As a result of these flow changes, many glaciers are now driving negative mass imbalances in West Antarctica (Shepherd and others, 2004; Thomas, 2004) and the Antarctic Peninsula (Pritchard and Vaughan, 2007). Changes in flow speed are often a glacier's dynamic response to climaterelated perturbations at its seaward margin (Payne and others, 2004; Scambos and others, 2004; Nick and others, 2009), although other mechanisms related to changes in subglacial hydrology might also play a role in speed increases (Stearns and others, 2008; Van de Wal and others, 2008).

The East Antarctic ice sheet (EAIS) is the largest reservoir of fresh water on Earth, with $\sim 50 \mathrm{~m}$ of sea-level rise equivalent. Current mass-balance estimates vary from -1 to $+67 \mathrm{~km}^{3} \mathrm{a}^{-1}$ (Shepherd and Wingham, 2007; Rignot and others, 2008), and while most of the growth is driven by enhanced snowfall over the ice-sheet interior (Davis and others, 2005), nearcoastal imbalances have been linked to ice dynamics (Rignot and Jacobs, 2002). Recent results from the Gravity Recovery and Climate Experiment (GRACE) suggest some ice mass loss in the coastal regions of the EAIS, but spatial aliasing makes it difficult to resolve the behavior of individual catchment basins (Chen and others, 2009; Wu and others, 2010). Because outlet glacier speeds exert a major control on icesheet mass balance and modulate ice-sheet contributions to sea-level rise, it is essential that their sensitivity to a range of dynamic processes is properly understood and incorporated into prognostic ice-sheet models.

Model studies (Dupont and Alley, 2005) suggest that glaciers with high driving stresses, large basal drag and minimal side drag (such as those draining through the Transantarctic Mountains) are more sensitive to changes in buttressing than other outlet glaciers. Consequently, modest thinning or retreat of the Ross Ice Shelf might initiate an adjustment in the flow speeds of Transantarctic Mountain outlet glaciers (Gagliardini and others, 2010). Recent observations (Stearns and others, 2008) also show that these glaciers are sensitive to varying inputs of subglacial water. These characteristics motivate the need for a better understanding of Transantarctic Mountain outlet glacier dynamics and mass balance.

Most of what is known about East Antarctic outlet glaciers draining into the Ross Ice Shelf has been gleaned from limited field programs in the early 1960s (Swithinbank, 1963), aerial photogrammetry from the late 1970s (Brecher, 1982) and recent satellite remote-sensing studies (Frezzotti and others, 1998; Rignot and Thomas, 2002; Schenk and others, 2005; Stearns, 2007). There have been no detailed, high-resolution field studies of the kind that have focused on the Siple Coast ice streams and Amundsen Sea embayment of West Antarctica. As a result, we have an incomplete understanding of many key details of the current configuration and dynamics of these glaciers, and are ill-equipped to model their response to potential future forcings.

Here the mass balance is estimated for four glaciers draining ice from the EAIS through the Transantarctic Mountains into the Ross Sea embayment: David Glacier $\left(75.3^{\circ} \mathrm{S}, 162^{\circ} \mathrm{E}\right)$, Mulock Glacier $\left(79^{\circ} \mathrm{S}, 160.5^{\circ} \mathrm{E}\right)$, Byrd Glacier $\left(80^{\circ} \mathrm{S}, 160^{\circ} \mathrm{E}\right)$ and Nimrod Glacier $\left(82.5^{\circ} \mathrm{S}\right.$, $160.2^{\circ} \mathrm{E}$ ) (Fig. 1). Together, these glaciers drain $\sim 1.53 \times 10^{6}$ $\mathrm{km}^{2}$ of East Antarctica. With the exception of David Glacier, they discharge ice into the Ross Ice Shelf. Remote-sensing observations are used to map changes in ice flow and surface elevation, and ultimately to compute the mass balance of each glacier using the input-output method.

\section{DATA AND METHODS}

Spatially extensive and multitemporal glaciological observations are limited for most Transantarctic Mountain outlet glaciers due to challenging field logistics and, until recently, 
sparse satellite coverage south of $\sim 81.5^{\circ} \mathrm{S}$. Here, imagery from the Advanced Spaceborne Thermal Emission and Reflection Radiometer (ASTER), which became available in 2000, is used to derive ice-velocity and surface-elevation maps over four Transantarctic Mountain glaciers. Landsat Thematic Mapper (TM), Landsat Enhanced TM+ (ETM+), Advanced Land Observing Satellite (ALOS) and Système Probatoire pour l'Observation de la Terre (SPOT) (Korona and others, 2009) imagery, where available, is used to extend the spatial and temporal coverage of the data. The images used in this study are listed in the Appendix.

\section{Velocity}

The ASTER sensor is well suited for mapping glaciers at high latitudes because it images at high resolution $(15 \mathrm{~m}$ pixel size in the visible/near-infrared (VNIR) bands) with coverage to $\sim 84^{\circ} \mathrm{N} / \mathrm{S}$. To obtain ice velocities, a cross-correlation technique (Scambos and others, 1992) is applied to sequential images to track the displacement of surface features such as crevasses. Cloud-free, co-registered and orthorectified image pairs are ingested to the software, and operator-controlled settings are used to maximize the statistical cross-correlation, based on variable flow speeds of each subsetted image. All the images are orthorectified using a reference digital elevation model (DEM), specifically chosen for each glacier based on adequate coverage of the glacier and surrounding mountains (which are needed for tie points). In many cases, the reference DEM is a mosaic of a few ASTER DEMs acquired on the same day.

The ASTER instrument's across-track, off-nadir scene acquisition capability $\left( \pm 24^{\circ}\right)$ in the VNIR introduces an image geometry change that must be considered during scene selection. Over regions of rugged relief, such as the Transantarctic Mountains, the pointing angles of sequential images must be within $3^{\circ}$ to maintain similar geometric characteristics (Stearns and Hamilton, 2007). If the pointing angle difference is $>3^{\circ}$, panoramic distortion inhibits cross-correlation.

The measured displacements of surface features have several sources of uncertainty originating from image orthorectification, co-registration and application of the feature-matching technique. Orthorectification using the ASTER DEM translates the DEM errors onto the orthorectified image. Kääb (2002) reports a $10 \mathrm{~m}$ ground position error for rough terrain in the Swiss Alps, which is smaller than the $30 \mathrm{~m}$ position error found by Stearns (2007) for East Greenland. Velocity errors are variable because of the different time separation of each image pair, but in all cases they are small in comparison to the observed speeds (Stearns, 2007).

Archival velocity measurements exist for some of the glaciers in this study. In 1960-62, Swithinbank (1963) measured surface displacement on Mulock, Byrd and Nimrod glaciers, using traditional theodolite observations. Surveys of each glacier consisted of one transverse profile, with 6-21 surveyed points. Brecher (1982) used aerial photographs of Byrd Glacier, acquired on 6 December 1978 and 31 January 1979, to calculate the displacement of 472 points on the glacier trunk. Velocity measurements on David Glacier derived from remote-sensing and field-based GPS were collected between 1990 and 1994 by Frezzotti and others (1998). Synthetic aperture radar interferometry (InSAR) was also used to measure ice velocities of David, Byrd and Mulock glaciers in 1997 (Rignot, 2002; Rignot and Thomas, 2002; Wuite and others, 2009).

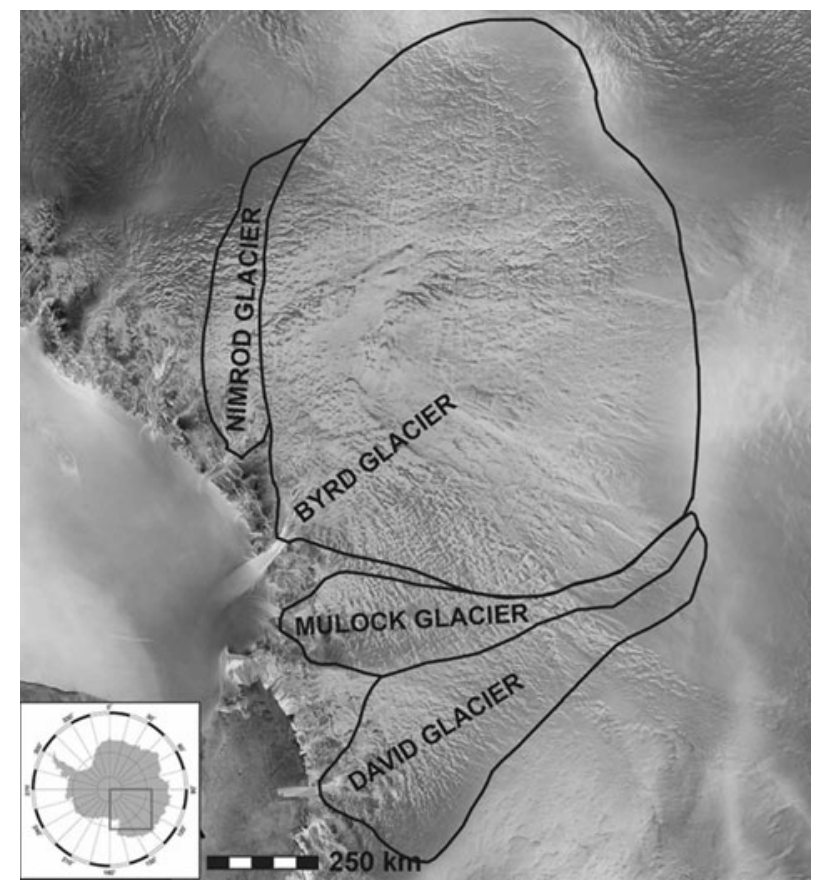

Fig. 1. Catchment boundaries for East Antarctic outlet glaciers studied in this paper, overlaid on a portion of the 1997 RADARSAT mosaic (Jezek and others, 2002). Together, these glaciers drain $\sim 1.53 \times 10^{6} \mathrm{~km}^{2}$ (or $12 \%$ by area) of the Antarctic ice sheet.

\section{Elevation data}

Surface elevation maps are produced from stereo ASTER imagery using the Japanese ASTER Science Team procedure described by Fujisada and others (2005) and Stearns and Hamilton (2007). The ASTER sensor collects a stereo imagepair using two telescopes in visible band 3: a nadir-viewing telescope $(3 \mathrm{~N})$ and a backward-looking telescope (3B). The individual ASTER scenes are converted to DEMs through processing of the stereo bands to epipolar geometry, and parallax-matching using commercial software, SILCAST (Fujisada and others, 2005). Products generated using identical procedures can be ordered from the NASA/US Geological Survey (USGS) Land Processes Distributed Active Archive Center (LP DAAC) at https://wist.echo.nasa.gov.api/. The final DEM product is referenced to the Earth Gravitational Model 1996 (EGM96) geoid, and has a grid spacing of $15 \mathrm{~m}$.

DEM uncertainties are from a combination of systematic errors, and random errors due to satellite positioning, image acquisition geometry and atmospheric conditions. Each DEM was tested for a systematic bias with respect to other DEMs of the same glacier; detected biases were removed. Calculated random errors contribute to a root-mean-square (rms) error of one pixel, based on a comparison of elevation differences in static regions (Stearns, 2007). This error is consistent with Fujisada and others (2005), who report a DEM vertical accuracy of $20 \mathrm{~m}$ with $95 \%$ confidence $(2 \sigma)$. In extremely rugged mountain regions, uncertainties in absolute elevations can be quite large $(\sim 60 \mathrm{~m} r \mathrm{rms})$, but uncertainties in relative elevations, important for surface elevation change and volume loss estimates, are usually much smaller (Kääb, 2002; Stearns and Hamilton, 2007). An error of $30 \mathrm{~m}$ is assigned to the ASTER DEMs, as long as quality-control tests over static regions (mountains) show only minor elevation differences between DEMs (Stearns, 2007). 


\section{Accumulation rates}

Snow accumulation is one of the most difficult mass-balance parameters to constrain (Eisen and others, 2008). There are $<100$ in situ surface mass-balance measurements in the catchment areas of the four outlet glaciers studied here, an area of $\sim 1.53 \times 10^{6} \mathrm{~km}^{2}$. These observations cover a range of time periods and are of variable quality. Several efforts have been made to incorporate the in situ measurements into continental-scale compilations using remote sensing, atmospheric reanalyses and statistical modeling (Vaughan and others, 1999; Arthern and others, 2006; Van de Berg and others, 2006). This study uses the results from these three compilations to calculate the catchment-specific mass balance. Both Vaughan and others (1999) and Arthern and others (2006) use satellite microwave radiometry (6.9 and $35 \mathrm{GHz}$, respectively) to extend the spatial distribution of surface measurements across the ice sheet. Thermal microwaves are emitted from the uppermost layers of the firn, but the actual depth depends on firn properties and the sensor wavelength, meaning the accumulation rates are unlikely to be averaged over a consistent time period. In comparison, Van de Berg and others (2006) use a regional atmospheric climate model, RACMO2/ANT, for the period 1980-2004, calibrated by field measurements, to produce their surface mass-balance map. RACMO2/ANT does parameterize sublimation, but snowdrift is not included (Van de Berg and others, 2006). Lenaerts and others (in press) performed RACMO simulations using the European Centre for MediumRange Weather Forecasts' (ECMWF) newest reanalysis dataset: ERA-Interim (1989-2009). ERA-Interim decreases precipitation inland compared to ERA-40, which was used by Van de Berg and others (2006). Moreover, the model by J. Lenaerts and others (unpublished information) includes snowdrift physics and yields very different accumulation values over the Antarctic plateau.

\section{Catchment area}

To compute mass balance, the size of the catchment basins over which snow accumulation occurs must be known. Catchment basins are delineated manually by mapping changes in surface slope on the OSU DEM of Antarctica (Jezek and others, 1999; Liu and others, 1999) and tracing flowlines and stripes on RADARSAT imagery. Price and Whillans (1998) assign an uncertainty of $9 \%$ to catchment basin areas, using traditional surveying techniques. The use of higher-resolution satellite-derived DEMs and imagery leads to improved catchment basin delineation; in this case, an uncertainty of $5 \%$ is applied. The catchment areas used in this study are within $3 \%$ of corresponding dimensions delineated in other studies (Frezzotti and others, 1998; Rignot and Jacobs, 2002; Rignot and Thomas, 2002).

\section{Grounding line}

The grounding line for each glacier was determined from a combination of surface slope flattening and reduction in driving stress (from $\sim 300 \mathrm{kPa}$ to $<10 \mathrm{kPa}$ ) (Stearns, 2007). Misplacing the grounding line will introduce an uncertainty into the computed discharge flux. The error is quantified as the difference between this study's grounding line location and grounding lines determined by surface flexure (Rignot and Jacobs, 2002; Brunt and others, 2010) and a combination of photoclinometry and laser altimetry (Bindschadler and others, 2011). Grounding lines are shown as being orthogonal to ice flow, which is probably a simplification of their actual curvilinear shape. However, this simplification is unlikely to substantially alter the calculated outgoing flux, since flow speeds near the margins are much slower.

\section{Mass balance}

The mass budget approach compares catchment-wide accumulation rates with ice flux across the grounding line. For a glacier in balance,

$$
\dot{M}=\dot{b}-\dot{m}-\bar{u}=0,
$$

in which accumulation rate, $\dot{b}$, is integrated over the catchment area. The basal melt rate, $\dot{m}$, is integrated over the zone of glacier sliding, and the depth-averaged velocity, $\bar{u}$, is integrated across the width of the grounding line. Ice discharge across the flux gate is referred to as flux ${ }_{\text {out }}$ throughout the text. The depth-averaged velocity is calculated using measured values of surface velocity $u_{\mathrm{s}}$

$$
\bar{u}=u_{\mathrm{s}}-\frac{2}{(n+1)(n+2)}\left(\frac{S_{\mathrm{f}} \rho_{\mathrm{ice}} g \sin \alpha}{B}\right)^{n} H^{n+1},
$$

where $n=3$, and $B$ is the stiffness parameter set to $500 \mathrm{kPa} \mathrm{a}^{-1 / 3}$ (appropriate for ice at $-15^{\circ} \mathrm{C}$ (Whillans and others, 1989)), $H$ is ice thickness, $g$ is the gravitational acceleration $\left(9.81 \mathrm{~m} \mathrm{~s}^{-2}\right), \alpha$ is the surface slope and $S_{\mathrm{f}}$ is the shape factor at the grounding line (equal to the crosssectional area divided by the product of the perimeter and ice thickness).

\section{Ice thickness}

Ice thickness at the grounding line, which is needed to determine flux $_{\text {out, }}$ is traditionally calculated from hydrostatic equilibrium, following

$$
H=\frac{h}{\left(1-\frac{\rho_{\text {ice }}}{\rho_{\text {water }}}\right)},
$$

in which $h$ is the ice surface elevation above sea level, and $\rho_{\text {ice }}$ and $\rho_{\text {water }}$ are the densities of ice $\left(900-917 \mathrm{~kg} \mathrm{~m}^{-3}\right)$ and sea water $\left(1027-1030 \mathrm{~kg} \mathrm{~m}^{-3}\right)$, respectively. Calculated ice thicknesses vary by $<12 \%$ between the maximum and minimum density values.

In reality, the column-averaged density across the grounding line will not be $917 \mathrm{~kg} \mathrm{~m}^{-3}$, but will include a layer of less-dense firn (Van den Broeke and others, 2008). A firn depth correction of $16 \mathrm{~m}$ is applied, following values cited in Van den Broeke and others (2008). This correction reduces the thickness values by $\leq 2 \%$. A $1 \sigma$ error of $100 \mathrm{~m}$ is applied to the ice thickness estimates, which accounts for uncertainties in grounding line location, density determination and firn compaction (this is comparable to errors applied to BEDMAP values (Lythe and others, 2001)).

\section{Basal melt}

Mass loss from basal melting arises from the conduction of geothermal heat into the ice and frictional energy dissipation at the bed. Melt rates could only be calculated for areas covered by the velocity maps, and yielded values ranging from $6 \mathrm{~mm}$ w.e. $\mathrm{a}^{-1}$ for Mulock Glacier to $260 \mathrm{~mm}$ w.e. $\mathrm{a}^{-1}$ for Byrd Glacier (Stearns, 2007). This variability is a function of different flow speeds, and magnitudes of driving stress and basal drag (Mulock Glacier has a comparatively low driving stress). 

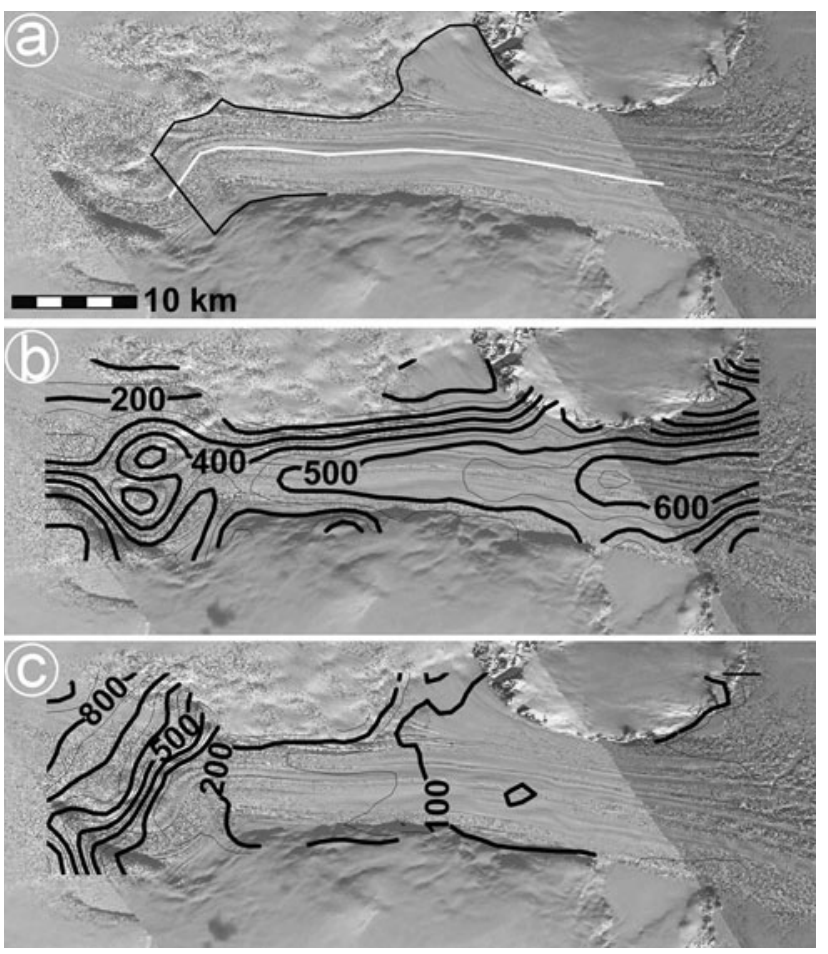

Fig. 2. David Glacier. (a) ASTER satellite image from 12 December 2004. David Cauldron is the steep drop to the left of the image. Ice flow is from left to right. The grounding line position (identified by Rignot (2002) and this study) is shown in black; the velocity profile used in Figure 3 is shown in white. (b) Ice velocity $\left(\mathrm{ma}^{-1}\right)$ determined from an ASTER image pair (17 January 2001/14 October 2001) and gridded to $1 \mathrm{~km}$. (c) Surface topography (m) derived from the ASTER image in (a) and gridded to $1 \mathrm{~km}$. The valley walls have been masked out.

\section{RESULTS}

\section{David Glacier}

David Glacier $\left(75.3^{\circ} \mathrm{S}, 162^{\circ} \mathrm{E}\right)$ drains ice from northern Victoria Land through the Transantarctic Mountains and into the Ross Sea (Fig. 2a). It is the only glacier in this study that is not buttressed by the Ross Ice Shelf, but rather feeds into the Drygalski Ice Tongue. The ice tongue extends $\sim 90 \mathrm{~km}$ into a polynya in Terra Nova Bay, which is kept free of sea ice by the force and persistence of katabatic winds (Kurtz and Bromwich, 1983). Earlier work shows that flow speeds on David Glacier increase almost linearly from the grounding line to the front of the Drygalski Ice Tongue (Frezzotti, 1993; Frezzotti and others, 2000; Wuite and others, 2009), which is consistent with the results from this study (Fig. 2b).

The trunk of David Glacier begins as ice flows over David Cauldron, a bedrock step that is evident in both satellite imagery (Fig. 2a) and surface topography (Fig. 2c). The glacier loses $400-500 \mathrm{~m}$ of elevation in David Cauldron, which causes a rapid, but isolated, flow acceleration (Fig. 2b). Down-flow of David Cauldron, the surface slope flattens and ice flow decreases. The glacier accelerates again as the tributary joins the main trunk. Throughout the trunk of David Glacier, flow speeds are much slower at the lateral margins, indicating the influence of lateral drag from the rock walls (Fig. 2b)

Rignot (2002) located the grounding line at the base of David Cauldron (Fig. 2a), based on tidal flexure detected using interferometry. Frezzotti and others (1998) had

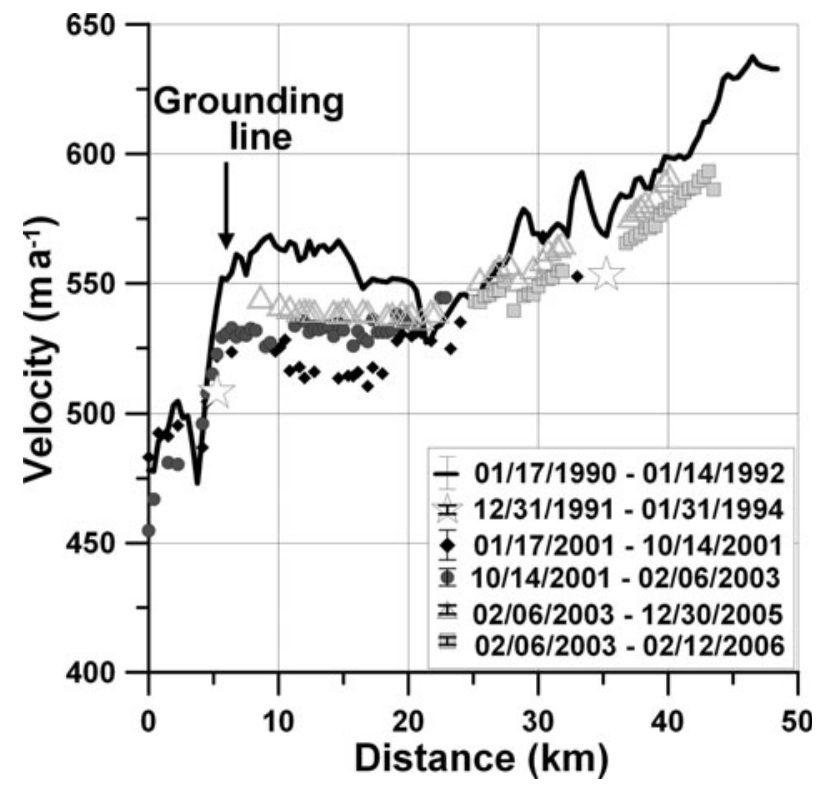

Fig. 3. David Glacier ice velocity derived from field surveys and repeat Landsat (Frezzotti and others, 1998) and ASTER images for five epochs along the white profile line in Figure 2a $(x=0$ is near David Cauldron; ice flow is from left to right). The solid black curve shows velocities derived from Landsat TM imagery (Frezzotti and others, 1998); the stars represent 1991-94 GPS velocities (Frezzotti and others, 1998). Error bars for each image pair are shown in the legend (dates are $\mathrm{mm} / \mathrm{dd} / \mathrm{yyyy}$ ).

previously placed the grounding line $\sim 15 \mathrm{~km}$ down-flow of David Cauldron, based on an analysis of tidal cycles in GPS observations carried out at eight locations along the glacier and the Drygalski Ice Tongue. The analysis of ASTER DEM slope changes places the grounding line near the Rignot (2002) position.

ASTER-derived velocities (2001-06) are compared with earlier results from Landsat TM images (Frezzotti and others, 1998), radar imagery from 1991 to 2000 (Wuite and others, 2009), and several GPS sites surveyed in 1991 and 1994 (Frezzotti and others, 1998) (Fig. 3). Flow speeds are generally within the respective errors, suggesting no significant changes in speed over the 16 year period. Ice velocity in 1990 is slightly higher (Fig. 3) than in subsequent years, particularly at the foot of David Cauldron, but with the current time series it is difficult to assess the cause or significance of this possible change in speed.

Existing mass-budget estimates for David Glacier indicate that it is close to zero balance (Frezzotti, 1993; Frezzotti and others, 2000; Rignot, 2002), with small differences in the estimates, probably arising from variability in the way that catchment-wide accumulation rates were quantified. The estimated flux $_{\text {out }}$ derived in this study $\left(9.28 \pm 0.88 \mathrm{Gta}^{-1}\right)$ is comparable to that estimated by Frezzotti and others (2000) $\left(9.1 \pm 0.9 \mathrm{Gt} \mathrm{a}^{-1}\right)$. Some mass-balance estimates (using snow-accumulation rates derived from historical snow-pit stratigraphy) suggest a large positive balance of $19.6 \mathrm{Gta}^{-1}$ (Giovinetto and Bentley, 1985) and $25.5 \mathrm{Gta}^{-1}$ (Vaughan and others, 1999) for David Glacier. These positive balances are not supported by surface elevation observations (Davis and others, 2005; Wingham and others, 2006; Helsen and others, 2008; Pritchard and others, 2009) or GRACE estimates (Ramillien and others, 2006; Chen and others, 2009), which suggest near-zero mass balance in this region. 


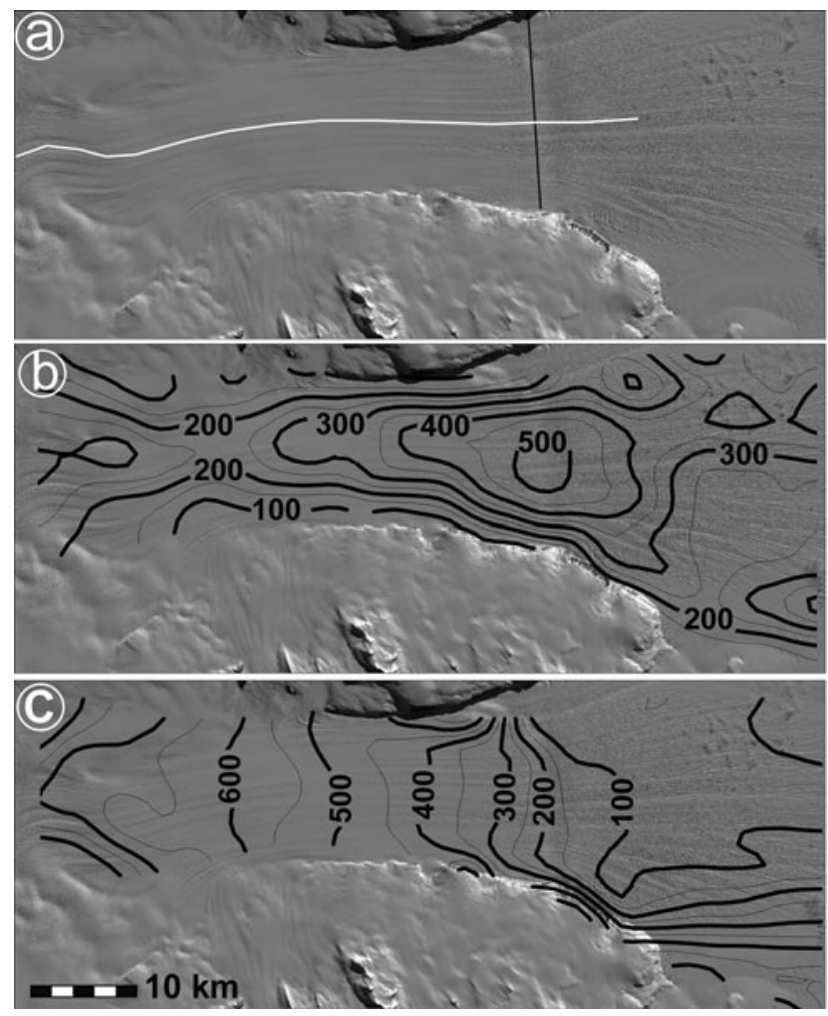

Fig. 4. Mulock Glacier. (a) ASTER satellite image from 23 November 2002. Ice flow is from left to right. The grounding line position is shown in black; the velocity profile used in Figure 3 is shown in white. (b) Ice velocity $\left(\mathrm{m} \mathrm{a}^{-1}\right)$ from an ASTER image pair (20 October 2001/23 November 2002), gridded to $1 \mathrm{~km}$ spacing. (c) Surface topography $(\mathrm{m})$ derived from the ASTER image in (a) and gridded to $1 \mathrm{~km}$ spacing.

\section{Mulock Glacier}

Mulock Glacier $\left(79^{\circ} \mathrm{S}, 160.5^{\circ} \mathrm{E}\right)$ drains the largest catchment basin between David and Byrd Glaciers (Fig. 4c). It is buttressed by the Ross Ice Shelf, and drains $5.23 \pm 0.59 \mathrm{Gt} \mathrm{a}^{-1}$ of ice from East Antarctica into the ice shelf. The net balance of Mulock Glacier $\left(1.91 \pm 0.84 \mathrm{Gta}^{-1}\right)$ suggests that it is roughly in balance with its catchment-wide accumulation; a finding consistent with Rignot and Thomas (2002).

The main trunk of Mulock Glacier is $\sim 60 \mathrm{~km}$ long (Fig. 4a) and undergoes a $\sim 800 \mathrm{~m}$ drop in elevation from the edge of the EAIS to the grounding line where it enters the Ross Ice Shelf (Fig. 4c). The ASTER-derived DEM shows large changes in surface concavity, which are most likely a function of flow across an overdeepened basin. Ice flow accelerates to accommodate discharge through a constriction in the fjord, and again as ice flows over a step into the Ross Ice Shelf (Fig. 4b). The sharp peak in velocity $\sim 50 \mathrm{~km}$ down the flowline (Fig. 5) is probably due to the increase in surface slope observed in the ASTER DEMs (Fig. 4c). The location of the grounding line is determined on the basis of crevasse patterns (Fig. 4a), ice flow (Fig. 5) and surfaceelevation changes (Fig. 4c).

Geodetic measurements from 1960-61 yielded ice velocities of $\sim 387 \mathrm{~m} \mathrm{a}^{-1}$ along the grounded center line of the glacier (Fig. 5) (Swithinbank, 1963). Results from repeat feature tracking, while not overlapping the same location, imply comparable ice speeds, 40 years after the Swithinbank (1963) study (Fig. 5). The more recent pattern of satellite

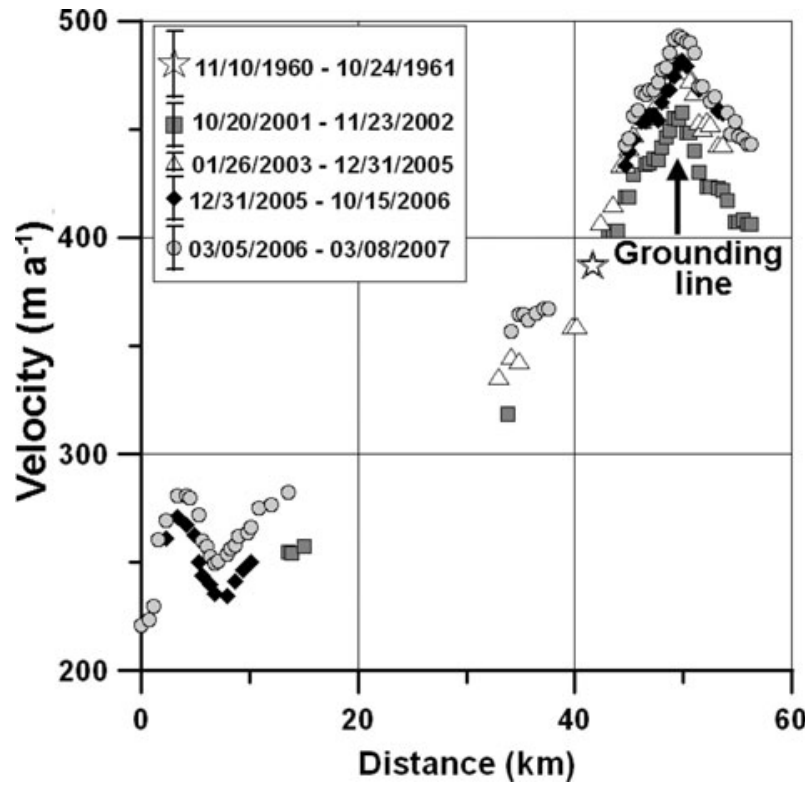

Fig. 5. Mulock Glacier ice velocity derived from repeat ASTER images for four epochs along the white line in Figure 4a. The star denotes repeat geodetic measurements by Swithinbank (1963). Error bars for each image pair are shown in the legend (dates are $\mathrm{mm} / \mathrm{dd} / \mathrm{yyyy})$.

image-derived velocities shows a gradual acceleration at the grounding line from $457 \pm 10 \mathrm{~m} \mathrm{a}^{-1}$ in 2001-02, to $481 \pm$ $8 \mathrm{ma}^{-1}$ in $2003-05$, to $493 \pm 20 \mathrm{ma}^{-1}$ in 2006-07. If the velocity increases are real, dynamic thinning should be detected along the length of the glacier: the uncertainties in the ASTER DEMs are too large to currently detect this effect (Stearns, 2007), but slight thinning $\left(\sim-3 \mathrm{~cm} \mathrm{a}^{-1}\right)$ is detected in firn-corrected maps of elevation change (Helsen and others, 2008).

\section{Byrd Glacier}

Byrd Glacier $\left(80^{\circ} \mathrm{S}, 160^{\circ} \mathrm{E}\right)$ has one of the largest catchment basins in Antarctica $\left(1101725 \mathrm{~km}^{2}\right)$, delivers $22.32 \pm$ $1.72 \mathrm{Gt} \mathrm{a}^{-1}$ of ice into the Ross Ice Shelf, and sustains rapid flow speeds in excess of $800 \mathrm{~m} \mathrm{a}^{-1}$. Prolonged changes in the flow dynamics of Byrd Glacier will have an impact on the mass balance of a significant portion of East Antarctica and might also affect the stability of the Ross Ice Shelf (Gagliardini and others, 2010).

A $\sim 10 \mathrm{~km}$ wide grounding zone was first identified by Hughes and Fastook (1981), who used traditional surveying techniques to detect tidal fluctuations at 15 surface elevation markers along the center line of Byrd Glacier (Fig. 6). Instead of a sharp grounding line, their data implied a gradual shift from floating to grounded ice (Hughes and Fastook, 1981). The grounding line might be prone to upglacier retreat because of high basal melt rates $\left(12-15 \mathrm{~m} \mathrm{a}^{-1}\right)$ along the floating part of Byrd Glacier (Kenneally and Hughes, 2004), a process that has been observed on other glaciers with floating tongues (Rignot, 2001; Rignot and Jacobs, 2002). In this study, the grounding line is identified (Fig. 6a) on the basis of changes in surface velocity (Fig. 7) and surface concavity (Fig. 6c). This grounding line is near the middle of the grounding zone identified by Hughes and Fastook (1981) and Bindschadler and others (2011) (dashed line in Fig. 6a). 

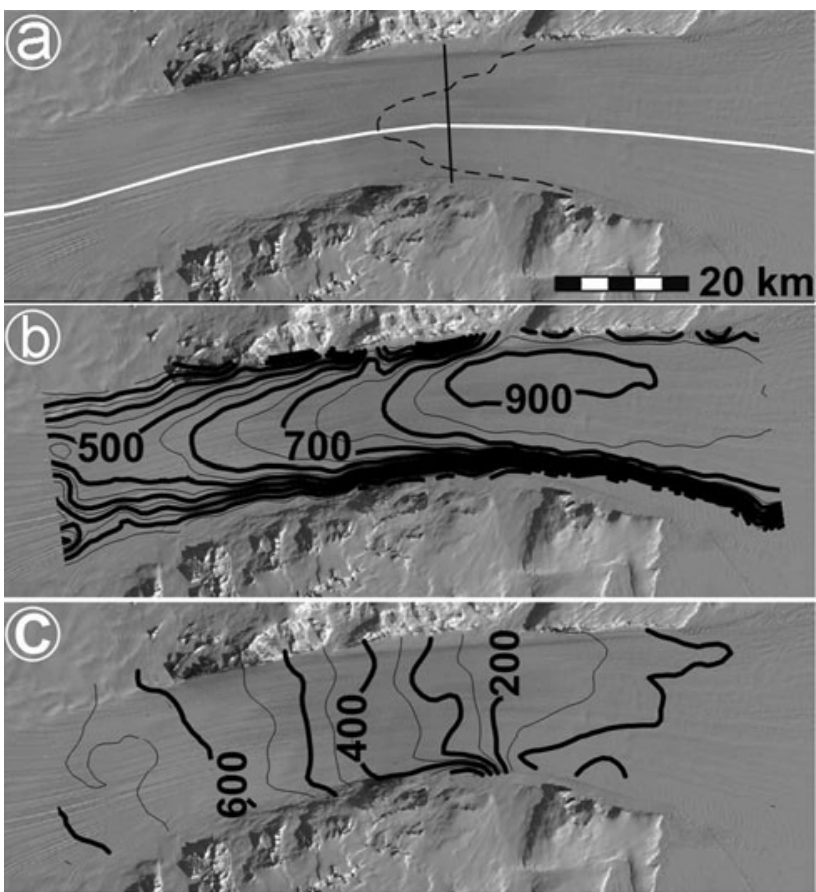

Fig. 6. Byrd Glacier. (a) Landsat satellite image from 20 January 1990. Ice flow is from left to right. The grounding line position is shown in black (solid line; located by this study), along with the grounding line identified by Bindschadler and others (2011) (dashed line); the velocity profile used in Figure 7 is shown in white. (b) Ice velocity $\left(\mathrm{m} \mathrm{a}^{-1}\right)$ from an ASTER image pair (5 December 2005/28 January 2007), gridded to $1 \mathrm{~km}$ spacing. (c) Surface topography $(\mathrm{m})$ derived from an ASTER image on 29 January 2001 and gridded to $1 \mathrm{~km}$.

The spatial pattern of ice velocity (Fig. 6b) can be explained by along-flow changes in surface topography (Fig. 7c). Ice velocity increases steadily along-flow in response to increases in surface slope (Fig. 7c). It peaks near the grounding line, and is concentrated towards the northern margin of the glacier. The velocity begins to decrease where linear flow switches to diverging shelf flow as the floating ice enters the Ross Ice Shelf.

Measurements from geodetic surveys (Swithinbank, 1963), repeat photogrammetry (Brecher, 1982) and satellite imaging techniques imply that flow speeds did not change between 1960 and 2005 (Fig. 7). Feature tracking performed on ASTER images acquired between December 2005 and January 2007 show accelerated flow speeds of $\sim 80 \mathrm{~m} \mathrm{a}^{-1}$ (Stearns and others, 2008). The speed-up extends from the floating tongue to $>75 \mathrm{~km}$ inland (Fig. 7). The acceleration, which began in late 2005, coincided with the inferred drainage of two subglacial lakes, located $200 \mathrm{~km}$ up-flow of the grounding line (Stearns and others, 2008). Based on Ice, Cloud and land Elevation Satellite (ICESat) observations, the lakes began refilling in late 2007; at the same time Byrd Glacier returned to its pre-acceleration speed. The discrete shift in flow speeds is illustrated in Figure 7.

There is currently no observed thinning on the grounded portion of Byrd Glacier, according to the differencing of ASTER DEMs. Schenk and others (2005) detect thinning of $10-30 \mathrm{~m}$ on the floating part of the glacier by comparing 1978 elevations from photogrammetry (Brecher, 1982) with 2004 elevations from ICESat. Assuming a constant rate of change, an elevation change of $2.4-7.2 \mathrm{~m}$ is expected during

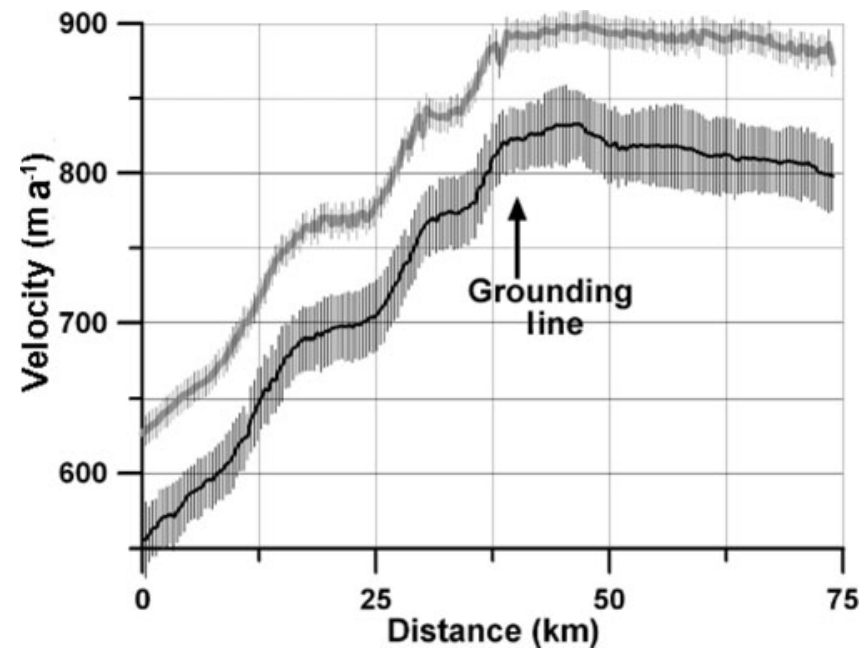

Fig. 7. Byrd Glacier ice velocity along the profile shown in Figure $6 \mathrm{a}$. The thin black line represents the mean of seven pre2005 ice velocity measurements (Stearns and others, 2008), with the vertical lines representing the standard deviation. The thicker grey curve represents the mean of ice velocity measurements (from four independent image pairs), derived during December 2005 and February 2007, when ice velocity was at its highest; the vertical lines represent the standard deviation.

the 2005-07 glacier speed-up, but this elevation change is too small to be detected with ASTER DEMs. Localized thinning exists in some parts of the Byrd catchment (Wingham and others, 2006; Helsen and others, 2008; Pritchard and others, 2009), and thickening is found in other regions (Davis and others, 2005; Wingham and others, 2006), but both trends are small and were determined using altimetry data that pre-date the acceleration of Byrd. Catchment-wide estimates suggest overall balance (Wingham and others, 2006; Helsen and others, 2008; Pritchard and others, 2009), although in each study only a fraction of the whole catchment contained data. Results from GRACE show no apparent mass change in this region of East Antarctica (Ramillien and others, 2006; Chen and others, 2009).

\section{Nimrod Glacier}

Nimrod Glacier $\left(82.5^{\circ} \mathrm{S}, 160.2^{\circ} \mathrm{E}\right)$ consists of two tributaries which merge $\sim 50 \mathrm{~km}$ from the Ross Ice Shelf (Fig. 8a). The contour plots in Figure 8 show ice velocity and surface elevation gridded to $1 \mathrm{~km}$. The DEM of Nimrod Glacier reveals steep slopes on the tributaries and flatter gradients farther down-glacier. Valley walls reduce the width of the glacier by $\sim 45 \%$ just below the confluence of the tributaries. This sudden narrowing causes a noticeable increase in velocity from $\sim 400 \mathrm{~m} \mathrm{a}^{-1}$ to $\sim 600 \mathrm{~m} \mathrm{a}^{-1}$ (Fig. 8b). Velocity decreases as the glacier widens and its slope decreases in the down-flow direction (Fig. 8c).

There is no detectable change in ice speed on Nimrod Glacier. Swithinbank (1963) conducted geodetic measurements on the floating portion of Nimrod Glacier in 1960-61. His results are not significantly different (Fig. 9) from velocity measurements derived from an ASTER image pair on 30 November 2004/15 December 2006, which is the only pair to overlap with his survey line. Ice velocity does not appear to change between 2001 and 2006, except for a slight acceleration from $238 \pm 13 \mathrm{~m} \mathrm{a}^{-1}$ to $264 \pm 11 \mathrm{~m} \mathrm{a}^{-1}$ at the grounding line (Fig. 9). 


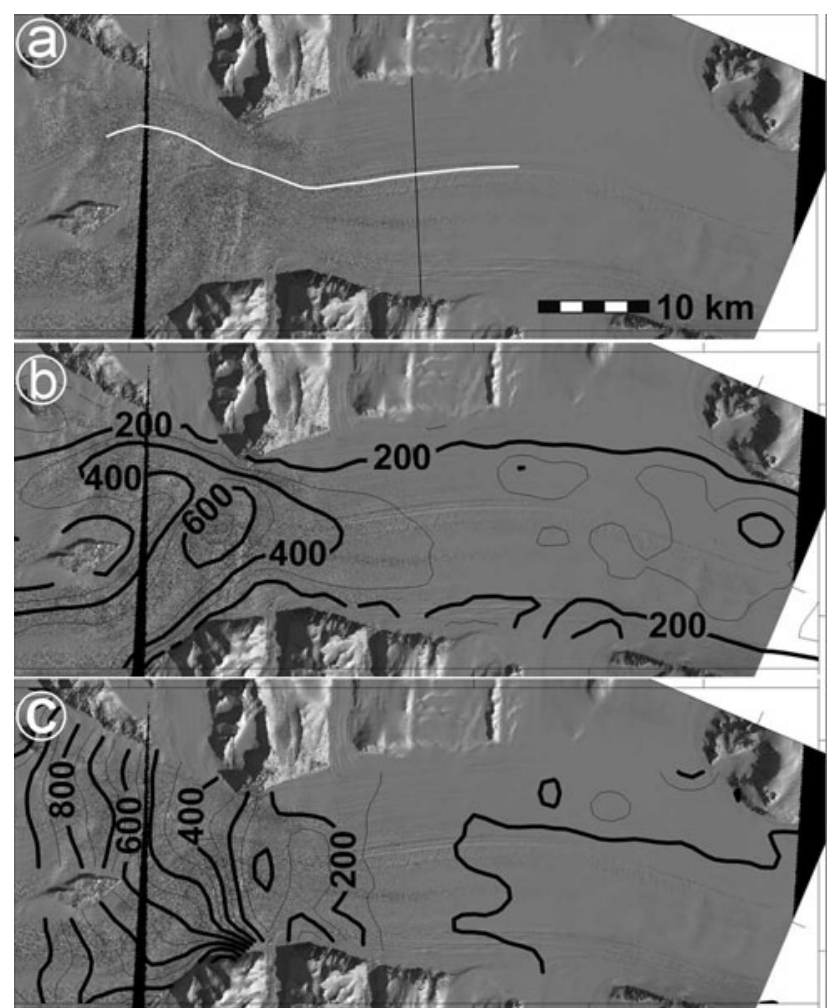

Fig. 8. Nimrod Glacier. (a) ASTER satellite image from 21 November 2001, with the grounding line (black line) and velocity profile (white line) for Figure 9 overlain. Ice flow is from left to right. (b) Ice velocity $\left(\mathrm{ma}^{-1}\right)$ from an ASTER image pair (28 January 2001/ 21 November 2001), gridded to $1 \mathrm{~km}$. (c) Surface topography (m) derived from the ASTER image in (a) and gridded to $1 \mathrm{~km}$.

The surface elevation of the grounded portion of Nimrod Glacier did not change from 2000 to 2006 (Stearns, 2007). Past the grounding line, there appears to be slight $\left(12.6 \pm 4.7 \mathrm{~m} \mathrm{a}^{-1}\right)$ thinning between 2000 and 2006. The net mass balance of Nimrod Glacier is $0.88 \pm 0.39 \mathrm{Gta}^{-1}$, suggesting it is roughly in balance with its catchment-wide accumulation.

\section{Mass balance}

The mass-balance estimates for each glacier basin are listed in Table 1. Accumulation rates, $\dot{b}$, are from the surface mass-balance compilation of Van de Berg and others (2006).

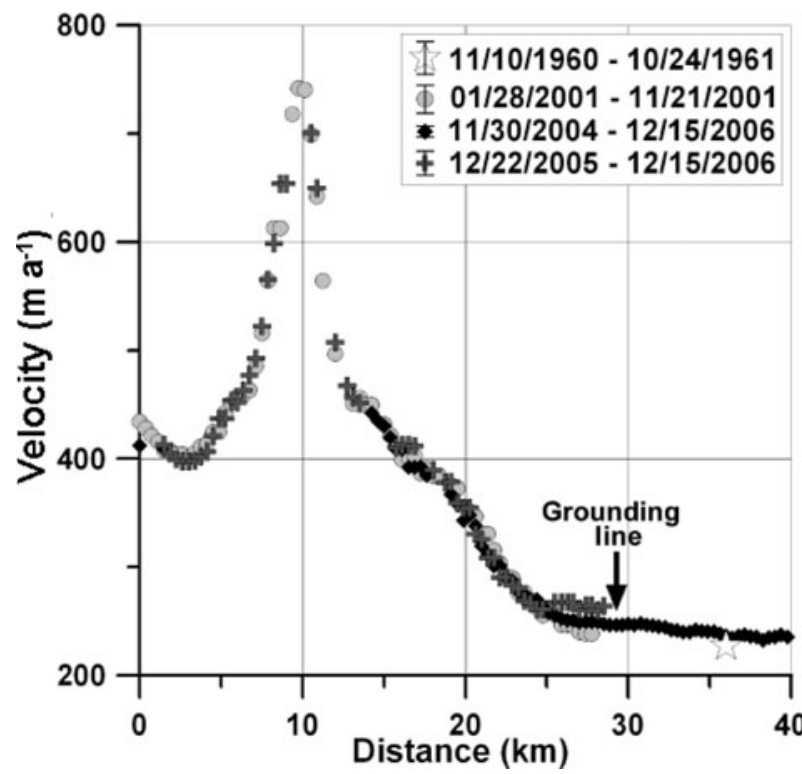

Fig. 9. Nimrod Glacier ice velocity derived from repeat geodetic measurements in 1960-61 by Swithinbank (1963) and ASTER imagery from 2001 to 2006. Grounding line, derived from changes in ASTER-derived surface slopes, is at $x \approx 30$. Error bars for each image pair are shown in the legend (dates are $\mathrm{mm} / \mathrm{dd} / \mathrm{yyyy}$ ).

The mass-balance results for David, Mulock and Nimrod glaciers all seem reasonable, given the general consistency in flow speed over the past few decades (Swithinbank, 1963; Frezzotti, 1993) and the lack of large elevation changes in the altimetry record (Davis and others, 2005; Wingham and others, 2006). The large positive balance for Byrd Glacier is a surprise; possible explanations are considered in the next section.

\section{DISCUSSION}

The input-output method of computing mass balance is sensitive to spatial variations in accumulation rate. Antarctic accumulation rate compilations rely on an irregular, lowdensity distribution of surface mass-balance measurements to guide the interpolation of low-resolution model output (Van de Berg and others, 2006) or remote-sensing observations (Vaughan and others, 1999; Arthern and others, 2006). For the $\sim 1.5 \times 10^{6} \mathrm{~km}^{2}$ catchment areas of David,

Table 1. Mass-balance results using accumulation estimates from Van de Berg and others (2006). Areas in parentheses are catchment areas. The year refers to the velocity data used to calculate fluxes. Variables are defined in Equation (1). The bottom two rows list mass-balance estimates derived from this study $\left(\dot{M}_{\text {Stearns }}\right)$ and Rignot and Thomas (2002) $\left(\dot{M}_{\text {Rignot }}\right)$. The Rignot and Thomas (2002) study did not include Nimrod Glacier (NA = not available)

\begin{tabular}{|c|c|c|c|c|}
\hline Variable & $\begin{array}{c}\text { David Glacier } \\
\left(218325 \pm 10916 \mathrm{~km}^{2}\right)\end{array}$ & $\begin{array}{c}\text { Mulock Glacier } \\
\left(123925 \pm 6196 \mathrm{~km}^{2}\right)\end{array}$ & $\begin{array}{c}\text { Byrd Glacier } \\
\left(1101725 \pm 55086 \mathrm{~km}^{2}\right)\end{array}$ & $\begin{array}{c}\text { Nimrod Glacier } \\
\left(84775 \pm 4238 \mathrm{~km}^{2}\right)\end{array}$ \\
\hline$\dot{b}\left(\mathrm{Gt} \mathrm{a}^{-1}\right)$ & $11.70 \pm 0.88$ & $7.15 \pm 0.54$ & $44.27 \pm 3.32$ & $4.27 \pm 0.24$ \\
\hline Year & 2001 & 2001 & 2006 & 2001 \\
\hline$\dot{m}\left(\mathrm{Gt} \mathrm{a}^{-1}\right)$ & 0.004 & 0.003 & 0.291 & 0.047 \\
\hline flux $_{\text {out }}\left(\mathrm{Gta}^{-1}\right)$ & $9.28 \pm 0.88$ & $5.23 \pm 0.59$ & $22.32 \pm 1.72$ & $3.34 \pm 0.17$ \\
\hline$\dot{M}_{\text {Rignot }}\left(\mathrm{Gt} \mathrm{a}^{-1}\right)$ & 1.8 & 0.9 & 19.3 & NA \\
\hline
\end{tabular}


Mulock, Byrd and Nimrod glaciers, there are $<100$ field measurements, and derived accumulation maps show large inter-map variability. The effect of inter-map variability is explored in Table 2 by assuming that each glacier is in steady state and then computing balance velocities ( $\left.\bar{u}_{\text {balance }}\right)$ required to discharge the mass prescribed by different compilations.

Observed velocities (in Table 2) are those derived from remote-sensing techniques described in the text. Balance velocities based on the Vaughan and others (1999) and Arthern and others (2006) accumulation rates are similar to one another, but consistently infer higher velocities than those observed. The differences in balance velocity are a function of the methods used to produce the compilations. Both Vaughan and others (1999) and Arthern and others (2006) use satellite microwave radiometry $(6.9$ and $35 \mathrm{GHz}$, respectively) to extend the spatial distribution of surface measurements. Van de Berg and others (2006) use a regional climate model, calibrated by field measurements, to produce their surface mass-balance map.

Table 2 shows that balance velocities computed using accumulation rates from Van de Berg and others (2006) consistently come closest to the observed velocities. The higher balance velocities required by the Vaughan and others (1999) and Arthern and others (2006) datasets imply that these compilations overestimate catchment-wide accumulation rates, at least in this part of Antarctica. Le Brocq and others (2010) note the reverse seems to be the case on a continent-wide basis, i.e. Van de Berg and others (2006) produce higher accumulations than Vaughan and others (1999) and Arthern and others (2006).

In addition, Magand and others (2007) suggest that, for a sector of East Antarctica from $90^{\circ} \mathrm{E}$ to $180^{\circ} \mathrm{E},>40 \%$ of the point measurements that constrain the surface mass-balance compilations are unreliable due to lack of quality control and measurement accuracy. Regional accumulation rates change significantly when the unreliable data points are removed (Magand and others, 2007). The greatest change is above $3000 \mathrm{~m}$, where there is a $20-30 \%$ reduction (Magand and others, 2007) in snow accumulation from the original compilations of Vaughan and others (1999), Arthern and others (2006) and Van de Berg and others (2006).

Discrepancies between ground-based measurements and accumulation compilation maps have been quantified for David Glacier basin, where Frezzotti and others (2007) found wind-driven sublimation can account for $20-75 \%$ of solid precipitation in high-slope areas. Similarly, preliminary results from a 2005 overland traverse in East Antarctica suggest that field-based measurements are 30-40\% lower (personal communication from D. Dixon, 2008) than estimates by Vaughan and others (1999) and Van de Berg and others (2006) in the same area. While differences between isolated field measurements and coarse-resolution continent-scale compilations are to be expected (Arthern and others, 2006), consistent and large discrepancies between independent compilations denote caution should be used when estimating the mass balance of individual drainage basins. Wind-driven ablation is an important mass loss process in most of East Antarctica (Scarchilli and others, 2010); this parameter is also difficult to quantify in surface accumulation maps. It is likely that accumulation overestimates, particularly in low-accumulation regions like East Antarctica, are due to the lack of constraints on wind-driven processes. A new model-based compilation (Lenaerts and
Table 2. Balance velocity $\left(\bar{u}_{\text {balance }}\right)$ estimates derived from three surface mass-balance compilations, compared to observed velocities $\left(\bar{u}_{\text {observed }}\right)$. The flux $x_{\text {out }}$ for Byrd Glacier is estimated using velocities derived in 2006

\begin{tabular}{lccc}
\hline Glacier & Model & $\begin{array}{c}\bar{u}_{\text {balance }} \\
\mathrm{m} \mathrm{a}^{-1}\end{array}$ & $\begin{array}{c}\bar{u}_{\text {observed }} \\
\mathrm{m} \mathrm{a}^{-1}\end{array}$ \\
\hline \multirow{2}{*}{ David } & Arthern and others (2006) & 734 & \\
& Vaughan and others (1999) & 655 & 369 \\
& Van de Berg and others (2006) & 403 & \\
Mulock & Arthern and others (2006) & 557 & \\
& Vaughan and others (1999) & 598 & 342 \\
& Van de Berg and others (2006) & 373 & \\
Byrd & Arthern and others (2006) & 1888 & \\
& Vaughan and others (1999) & 1836 & 672 \\
& Van de Berg and others (2006) & 1408 & \\
Nimrod & Arthern and others (2006) & 386 & \\
& Vaughan and others (1999) & 409 & 203 \\
& Van de Berg and others (2006) & 277 & \\
\hline
\end{tabular}

others, in press), which accounts for snowdrift physics, reveals generally smaller snow accumulation values on the East Antarctic plateau.

Other possible explanations for the calculated imbalance of Byrd Glacier are explored below, but none of them are as plausible as the aforementioned overestimates in accumulation rate.

1. The calculated mass gain $\left(21.67 \pm 4.04 \mathrm{Gta}^{-1}\right.$; Table 1$)$ would be viable if Byrd Glacier were thickening at a rate of $\sim 6 \mathrm{~cm} \mathrm{a}^{-1}$ throughout its catchment. Satellite radar altimetry maps for the period 1992-2003 show slight thickening $\left(0.0-0.4 \mathrm{~cm} \mathrm{a}^{-1}\right)$ in parts of the Byrd catchment (Davis and Ferguson, 2004; Wingham and others, 2006), but this is well below the inferred rate mentioned above. Davis and others (2005) infer an increase in snowfall in several East Antarctic catchments between the early and late 1990s, by comparing radar altimetry measurements in 1992, 1995 and 2000. However, the Byrd Glacier catchment has a net thinning of $-1.0 \pm$ $1.2 \mathrm{~cm} \mathrm{a}^{-1}$ in that study (Davis and others, 2005). Their overall thinning, which is enhanced at the margins, is also detected with ICESat elevation change estimates (Pritchard and others, 2009). An analysis of repeat ASTER DEMs over Byrd shows no elevation change, although the uncertainties are large.

2. In order to accommodate the large $\dot{b}$ suggested in the compilations, Byrd Glacier would need to be flowing almost twice as fast as currently measured (Table 2). In Table 1, the mass balance of Byrd Glacier is reported using velocities derived during its speed-up (Stearns and others, 2008), not during the time of steady flow. This is to show that, even when Byrd Glacier accelerated by $80 \mathrm{~m} \mathrm{a}^{-1}$, it did not flow fast enough to get rid of the snow accumulation estimated from various surface massbalance compilations. The positive mass imbalance, using pre-acceleration velocities, is even larger $\left(23.63 \pm 4.02 \mathrm{Gta}^{-1}\right)$. There is no evidence in the velocity record (1963-2004; Fig. 7) of an earlier phase of 
sustained and enhanced ice discharge, suggesting that the glacier was in steady state with catchment accumulation during this time period.

3. An erroneously high catchment-wide accumulation rate could be the result of an overestimated catchment area. In this study, the Byrd Glacier catchment basin was delineated using a continental DEM (Liu and others, 1999) and RADARSAT imagery to map the ice divides and flow directions. The catchment basin area, estimated to be $1101725 \pm 55086 \mathrm{~km}^{2}$, is consistent with an estimate of $1070400 \mathrm{~km}^{2}$ by Rignot and Thomas (2002). Given an average $\dot{b}$ value of $400 \mathrm{~mm} \mathrm{a}^{-1}$ (Van de Berg and others, 2006), the Byrd catchment would need to be less than two-thirds its size $\left(\sim 600000 \mathrm{~km}^{2}\right)$ to be in steady state with its calculated flux $x_{\text {out }}$.

4. An inaccurate ice thickness at the grounding line could lead to an underestimated flux out $_{\text {component of the }}$ balance equation, and a calculated positive imbalance. However, the flux gate would need to be almost twice as large $\left(71.3 \mathrm{~km}^{2}\right.$, and not $\left.34.3 \mathrm{~km}^{2}\right)$ in order for Byrd Glacier to be in balance with the prescribed accumulation rates; since the fjord walls do not accommodate widening, this would mean $1350 \mathrm{~m}$ thicker ice, which is clearly implausible.

The simplest explanation for Byrd Glacier's calculated imbalance is that a small overestimate in accumulation rate leads to a large error in mass input when scaled to the glacier's large catchment.

\section{CONCLUSIONS}

Outlet glaciers flowing through the Transantarctic Mountains are important pathways for ice to drain from the EAIS into the Ross Ice Shelf. Mass balance computed using the flux method indicates small positive balances for David $\left(2.41 \pm 1.31 \mathrm{Gta}^{-1}\right)$, Mulock $\left(1.91 \pm 0.84 \mathrm{Gta}^{-1}\right)$ and Nimrod $\left(0.88 \pm 0.39 \mathrm{Gta}^{-1}\right)$ glaciers (Table 1$)$. These results are consistent with Rignot and Thomas (2002) for all but David Glacier, where Rignot and Thomas (2002) estimate a negative balance of $2 \mathrm{Gta}^{-1}$. This difference is probably due to discrepancies in surface accumulation estimates. The results also highlight a large imbalance for Byrd Glacier $\left(21.67 \pm 4.04 \mathrm{Gta}^{-1}\right)$ which is likely due to overestimated catchment-wide accumulation rates. In order to improve basin-wide mass-balance estimates, additional accumulation and ice thickness measurements are needed.

\section{ACKNOWLEDGEMENTS}

This work is an extension of work that L.A.S. did as part of her PhD thesis at the University of Maine. G.S. Hamilton provided invaluable support throughout the project. This work was supported by NASA's Cryospheric Sciences Program through NNG04-GK39G (G.S. Hamilton) and a NASA Earth Systems Science Fellowship (L.A.S.). I thank C. Swithinbank for providing raw data and maps from his 1961 Antarctic field season; B. Lucchitta and T. Hughes for providing Landsat TM4 scenes of Byrd Glacier; and W.-J. van de Berg and J. Lenaerts for generously sharing their modeled surface mass-balance data for this study. Two anonymous reviewers and associate editor D. van As provided comments which greatly improved the manuscript.

\section{REFERENCES}

Arthern, R.J., D.P. Winebrenner and D.G. Vaughan. 2006. Antarctic snow accumulation mapped using polarization of $4.3-\mathrm{cm}$ wavelength microwave emission. J. Geophys. Res., 111(D6), D06107. (10.1029/2004JD005667.)

Bindschadler, R.A., M.A. King, R.B. Alley, S. Anandakrishnan and L. Padman. 2003. Tidally controlled stick-slip discharge of a West Antarctic ice stream. Science, 301(5636), 1087-1089.

Bindschadler, R. and 17 others. 2011. Getting around Antarctica: new high-resolution mappings of the grounded and freelyfloating boundaries of the Antarctic ice sheet created for the International Polar Year. Cryos. Discuss., 5(1), 183-227.

Brecher, H.H. 1982. Photographic determination of surface velocities and elevations on Byrd Glacier. Antarct. J. US, 17(5), 79-81.

Brunt, K.M., H.A. Fricker, L. Padman, T.A. Scambos and S. O'Neel. 2010. Mapping the grounding zone of Ross Ice Shelf, Antarctica, using ICESat laser altimetry. Ann. Glaciol., 51(55), 71-79.

Chen, J.L., C.R. Wilson, D. Blankenship and B.D. Tapley. 2009. Accelerated Antarctic ice loss from satellite gravity measurements. Nature Geosci., 2(12), 859-862.

Davis, C.H. and A.C. Ferguson. 2004. Elevation change of the Antarctic ice sheet, 1995-2000, from ERS-2 satellite radar altimetry. IEEE Trans. Geosci. Remote Sens., 42(11), 2437-2445.

Davis, C.H., Y. Li, J.R. McConnell, M.M. Frey and E. Hanna. 2005. Snowfall-driven growth in East Antarctic ice sheet mitigates recent sea-level rise. Science, 308(5730), 1898-1901.

Dupont, T.K. and R.B. Alley. 2005. Assessment of the importance of ice-shelf buttressing to ice-sheet flow. Geophys. Res. Lett., 32(4), L04503. (10.1029/2004GL022024.)

Eisen, O. and 15 others. 2008. Ground-based measurements of spatial and temporal variability of snow accumulation in East Antarctica. Rev. Geophys., 46(RG2), RG2001. (10.1029/ 2006RG000218.)

Frezzotti, M. 1993. Glaciological study in Terra Nova Bay, Antarctica, inferred from remote-sensing analysis. Ann. Glaciol., 17, 63-71.

Frezzotti, M., A. Capra and L. Vittuari. 1998. Comparison between glacier ice velocities inferred from GPS and sequential satellite images. Ann. Glaciol., 27, 54-60.

Frezzotti, M., I.E. Tabacco and A. Zirizzotti. 2000. Ice discharge of eastern Dome C drainage area, Antarctica, determined from airborne radar survey and satellite image analysis. J. Glaciol., 46(153), 253-264.

Frezzotti, M., S. Urbini, M. Proposito, C. Scarchilli and S. Gandolfi. 2007. Spatial and temporal variability of surface mass balance near Talos Dome, East Antarctica. J. Geophys. Res., 112(F2), F02032. (10.1029/2006JF000638.)

Fujisada, H., G.B. Bailey, G.G. Kelly, S. Hara and M.J. Abrams. 2005. ASTER DEM performance. IEEE Trans. Geosci. Remote Sens., 43(12), 2707-2714.

Gagliardini, O., G. Durand, T. Zwinger, R.C.A. Hindmarsh and E. Le Meur. 2010. Coupling of ice-shelf melting and buttressing is a key process in ice-sheets dynamics. Geophys. Res. Lett., 37(14), L14501. (10.1029/2010GL043334.)

Giovinetto, M.B. and C.R. Bentley. 1985. Surface balance in ice drainage systems of Antarctica. Antarct. J. US, 20(4), 6-13.

Helsen, M.M. and 7 others. 2008. Elevation changes in Antarctica mainly determined by accumulation variability. Science, 320(5883), 1626-1629.

Hughes, T.J. and J.L. Fastook. 1981. Byrd Glacier: 1978-1979 field results. Antarct. J. US, 16(5), 86-89.

Hulbe, C. and M. Fahnestock. 2007. Century-scale discharge stagnation and reactivation of the Ross ice streams, West Antarctica. J. Geophys. Res., 112(F3), F03S27. (10.1029/ 2006JF000603.)

Jezek, K.C., H. Liu, Z. Zhao and B. Li. 1999. Improving a digital elevation model of Antarctica using radar remote sensing data and GIS techniques. Polar Geogr., 23(3), 185-200. 
Joughin, I., E. Rignot, C.E. Rosanova, B.K. Lucchitta and J. Bohlander. 2003. Timing of recent accelerations of Pine Island Glacier, Antarctica. Geophys. Res. Lett., 30(13), 1706. (10.1029/ 2003GL017609.)

Kääb, A. 2002. Monitoring high-mountain terrain deformation from repeated air- and spaceborne optical data: examples using digital aerial imagery and ASTER data. ISPRS J. Photogramm. Remote Sens., 57(1-2), 39-52.

Kenneally, J.P. and T.J. Hughes. 2004. Basal melting along the floating part of Byrd Glacier. Antarct. Sci., 16(3), 355-358.

Korona, J., E. Berthier, M. Bernard, F. Rémy and E. Thouvenot. 2009. SPIRIT. SPOT 5 stereoscopic survey of Polar Ice: Reference Images and Topographies during the fourth International Polar Year (2007-2009). ISPRS J. Photogramm. Rem. Sens., 64(2), $2823-2830$

Kurtz, D.D. and D.H. Bromwich. 1983. Satellite observed behavior of the Terra Nova Bay polynya. J. Geophys. Res. 88(C14), 9717-9722.

Le Brocq, A.M., A.J. Payne and A. Vieli. 2010. An improved Antarctic dataset for high resolution numerical ice sheet models (ALBMAP v1). Earth Syst. Sci. Data, 2(2), 247-260.

Lenaerts, J., M.R. van den Broeke, W.J. van de Berg, E. van Meijgaard and P. Kuipers Munneke. In press. A new, highresolution surface mass balance map of Antarctica (1989-2009) based on regional atmospheric climate modeling. Geophys. Res. Lett.

Liu, H., K.C. Jezek and B. Li. 1999. Development of an Antarctic digital elevation model by integrating cartographic and remotely sensed data: a geographic information system based approach. J. Geophys. Res., 104(B10), 23,199-23,213.

Lythe, M.B., D.G. Vaughan and BEDMAP consortium. 2001. BEDMAP: a new ice thickness and subglacial topographic model of Antarctica. J. Geophys. Res., 106(B6), 11,335-11,351.

Magand, O. and 6 others. 2007. An up-to-date quality-controlled surface mass balance data set for the $90^{\circ}-180^{\circ} \mathrm{E}$ Antarctica sector and 1950-2005 period. J. Geophys. Res., 112(D12), D12106. (10.1029/2006JD007691.)

Nick, F.M., A. Vieli, I.M. Howat and I. Joughin. 2009. Large-scale changes in Greenland outlet glacier dynamics triggered at the terminus. Nature Geosci., 2(2), 110-114.

Payne, A.J., A. Vieli, A. Shepherd, D.J. Wingham and E. Rignot. 2004. Recent dramatic thinning of largest West Antarctic ice stream triggered by oceans. Geophys. Res. Lett., 31(23), L23401. (10.1029/2004GL021284.)

Price, S.F. and I.M. Whillans. 1998. Delineation of a catchment boundary using velocity and elevation measurements. Ann. Glaciol., 27, 140-144

Pritchard, H.D. and D.G. Vaughan. 2007. Widespread acceleration of tidewater glaciers on the Antarctic Peninsula. J. Geophys. Res., 112(F3), F03S29. (10.1029/2006JF000597.)

Pritchard, H.D., R.J. Arthern, D.G. Vaughan and L.A. Edwards. 2009. Extensive dynamic thinning on the margins of the Greenland and Antarctic ice sheets. Nature, 461(7266), 971-975.

Ramillien, G. and 6 others. 2006. Interannual variations of the mass balance of the Antarctica and Greenland ice sheets from GRACE. Global Planet. Change, 53(3), 198-208.

Retzlaff, R., N. Lord and C.R. Bentley. 1993. Airborne-radar studies: Ice Streams A, B and C, West Antarctica. J. Glaciol., 39(133), 495-506.

Rignot, E. 2001. Evidence for rapid retreat and mass loss of Thwaites Glacier, West Antarctica. J. Glaciol., 47(157), 213-222.

Rignot, E. 2002. Mass balance of East Antarctic glaciers and ice shelves from satellite data. Ann. Glaciol., 34, 217-227.

Rignot, E. and S.S. Jacobs. 2002. Rapid bottom melting widespread near Antarctic ice sheet grounding lines. Science, 296(5575), 2020-2023.

Rignot, E. and R.H. Thomas. 2002. Mass balance of polar ice sheets. Science, 297(5586), 1502-1506.
Rignot, E. and 6 others. 2008. Recent Antarctic ice mass loss from radar interferometry and regional climate modelling. Nature Geosci., 1(2), 106-110.

Scambos, T.A., M.J. Dutkiewicz, J.C. Wilson and R.A. Bindschadler. 1992. Application of image cross-correlation to the measurement of glacier velocity using satellite image data. Remote Sens. Environ., 42(3), 177-186.

Scambos, T.A., J.A. Bohlander, C.A. Shuman and P. Skvarca. 2004. Glacier acceleration and thinning after ice shelf collapse in the Larsen B embayment, Antarctica. Geophys. Res. Lett., 31(18), L18402. (10.1029/2004GL020670.)

Scarchilli, C., M. Frezzotti, P. Grigioni, L. De Silvestri, L. Agnoletto and S. Dolci. 2010. Extraordinary blowing snow transport events in East Antarctica. Climate Dyn., 34(7-8), 1195-1206.

Schenk, T., B. Csatho, C.J. van der Veen, H. Brecher, Y. Ahn and T. Yoon. 2005. Registering imagery to ICESat data for measuring elevation changes on Byrd Glacier, Antarctica. Geophys. Res. Lett., 32(23), L23S05. (10.1029/2005GL024328.)

Shepherd, A. and D. Wingham. 2007. Recent sea-level contributions of the Antarctic and Greenland ice sheets. Science, 315(5818), 1529-1532.

Shepherd, A., D. Wingham and E. Rignot. 2004. Warm ocean is eroding West Antarctic Ice Sheet. Geophys. Res. Lett., 31(23), L23404. (10.1029/2004GL021106.)

Stearns, L.A. 2007. Outlet glacier dynamics in East Greenland and East Antarctica. (PhD thesis, University of Maine.)

Stearns, L.A. and G.S. Hamilton. 2007. Rapid volume loss from two East Greenland outlet glaciers quantified using repeat stereo satellite imagery. Geophys. Res. Lett., 34(5), L05503. (10.1029/ 2006GL028982.)

Stearns, L.A., K.C. Jezek and C.J. van der Veen. 2005. Decadalscale variations in ice flow along Whillans Ice Stream and its tributaries, West Antarctica. J. Glaciol., 51(172), 147-157.

Stearns, L.A., B.E. Smith and G.S. Hamilton. 2008. Increased flow speed on a large East Antarctic outlet glacier caused by subglacial floods. Nature Geosci., 1(12), 827-831.

Swithinbank, C.W. 1963. Ice movement of valley glaciers flowing into the Ross Ice Shelf, Antarctica. Science, 141(3580), 523-524.

Thomas, R.H. 2004. Force-perturbation analysis of recent thinning and acceleration of Jakobshavn Isbræ, Greenland. J. Glaciol., 50(168), 57-66.

Van de Berg, W.J., M.R. van den Broeke, C.H. Reijmer and E. van Meijgaard. 2006. Reassessment of the Antarctic surface mass balance using calibrated output of a regional atmospheric climate model. J. Geophys. Res., 111(D11), D11104. (10.1029/ 2005JD006495.)

Van de Wal, R.S.W. and 6 others. 2008. Large and rapid meltinduced velocity changes in the ablation zone of the Greenland Ice Sheet. Science, 321(5885), 111-113.

Van den Broeke, M., W.J. van de Berg and E. van Meijgaard. 2008. Firn depth correction along the Antarctic grounding line. Antarct. Sci., 20(5), 513-517.

Vaughan, D.G., J.L. Bamber, M.B. Giovinetto, J. Russell and A.P.R. Cooper. 1999. Reassessment of net surface mass balance in Antarctica. J. Climate, 12(4), 933-946.

Whillans, I.M., Y.H. Chen, C.J. van der Veen and T.J. Hughes. 1989. Force budget: III. Application to three-dimensional flow of Byrd Glacier, Antarctica. J. Glaciol., 35(119), 68-80.

Wingham, D.J., A. Shepherd, A. Muir and G.J. Marshall. 2006. Mass balance of the Antarctic ice sheet. Philos. Trans. R. Soc. London, Ser. A, 364(1844), 1627-1635.

Wu, X.M. and 8 others. 2010. Simultaneous estimation of global present-day water transport and glacial isostatic adjustment. Nature Geosci., 3(9), 642-646.

Wuite, J., K.C. Jezek, X. Wu, K. Farness and R. Carande. 2009. The velocity field and flow regime of David Glacier and Drygalski Ice Tongue, Antarctica. Polar Geogr., 32(3-4), 111-127. 


\section{APPENDIX}

Images used in this paper.

\begin{tabular}{|c|c|c|c|c|c|}
\hline Acquisition & Sensor & Scene ID & Acquisition & Sensor & Scene ID \\
\hline \multicolumn{6}{|l|}{ Byrd Glacier } \\
\hline 22 Feb 1988 & Landsat TM & LT4045119120088053 & 17 Jan 1990 & Landsat ETM & LT4062114199001705 \\
\hline 8 Feb 1989 & Landsat TM & LT4045119120089039 & 17 Jan 2001 & ASTER & 00301172001212608 \\
\hline 29 Jan 1990 & Landsat TM & LT4050118119090029 & 14 Oct 2001 & ASTER & 00310142001213212 \\
\hline 24 Dec 1999 & Landsat ETM & LE750118009935850 & 6 Feb 2003 & ASTER & 00302062003212739 \\
\hline 29 Jan 2001 & ASTER & $\begin{array}{l}00301292001201357 \\
00301292001201406\end{array}$ & 30 Dec 2005 & ASTER & 00312302005211258 \\
\hline \multirow[t]{2}{*}{9 Dec 2001} & ASTER & $\begin{array}{l}00312092001204213 \\
00312092001204222\end{array}$ & 12 Feb 2006 & ASTER & 00312302005211307 \\
\hline & & 00312092001204231 & Mulock Glacier & & \\
\hline 31 Dec 2001 & Landsat ETM & LE7104811920011231 & 12 Oct 2001 & ASTER & 00310122001200720 \\
\hline \multirow[t]{2}{*}{$16 \operatorname{Jan} 2002$} & ASTER & 00301162002200419 & 20 Oct 2001 & ASTER & 00310202001205606 \\
\hline & & 00301162002200428 & 23 Nov 2002 & ASTER & 00311232002200859 \\
\hline 8 Dec 2004 & ASTER & 00312082004190548 & 26 Jan 2003 & ASTER & 00301262003200856 \\
\hline 10 Dec 2004 & ASTER & & 31 Dec 2005 & ASTER & 00312312005152543 \\
\hline \multirow[t]{2}{*}{5 Dec 2005} & ASTER & 00312052005194240 & & & 00312312005201849 \\
\hline & & 00312052005194249 & 5 Mar 2006 & ASTER & 00303052006201911 \\
\hline 2 Jan 2006 & ASTER & 00301022006200650 & 15 Oct 2006 & ASTER & 00310152006201912 \\
\hline 23 Dec 2006 & ALOS* & ALAV2A048685300 & 8 Mar 2007 & ASTER & 00303082007202023 \\
\hline \multirow[t]{2}{*}{21 Jan 2007} & ASTER & 00301212007200804 & \multicolumn{3}{|l|}{ Nimrod Glacier } \\
\hline & & 00301212007200813 & 28 Jan 2001 & ASTER & 00301282001193116 \\
\hline \multirow[t]{2}{*}{28 Jan 2007} & ASTER & 00301282007201419 & \multirow{2}{*}{21 Nov 2001} & \multirow{2}{*}{ ASTER } & 00311212001191718 \\
\hline & & 00301282007201428 & & & 00311212001191727 \\
\hline 7 Feb 2007 & ALOS* & LAV2A05539530 & \multirow{2}{*}{30 Nov 2004} & \multirow[t]{2}{*}{ ASTER } & 00311302004181638 \\
\hline \multirow[t]{2}{*}{6 Dec 2007} & $\mathrm{SPOT}^{\dagger}$ & $50525670712061932292 \mathrm{~S}$ & & & 00311302004181647 \\
\hline & & $50525670712061932382 \mathrm{~S}$ & \multirow[t]{2}{*}{22 Dec 2005} & \multirow[t]{2}{*}{ ASTER } & 00312222005184727 \\
\hline 28 Dec 2007 & ASTER & 00312282007184835 & & & 00312222005184735 \\
\hline \multirow{2}{*}{17 Jan 2008} & $\mathrm{SPOT}^{\dagger}$ & 00312282007184843 & \multirow[t]{2}{*}{15 Dec 2006} & \multirow[t]{2}{*}{ ASTER } & 00312152006181117 \\
\hline & SPOT' & $\begin{array}{l}50535680801171924262 S \\
50545700801171924352 S\end{array}$ & & & 00312152006181126 \\
\hline 11 Dec 2008 & Landsat ETM & L7204711911920081211 & & & \\
\hline 31 Jan 2009 & ASTER & 00301312009184925 & & & \\
\hline
\end{tabular}

